Article

\title{
Landslides Triggered by the 2016 Mw 7.8 Pedernales, Ecuador Earthquake: Correlations with ESI-07 Intensity, Lithology, Slope and PGA-h
}

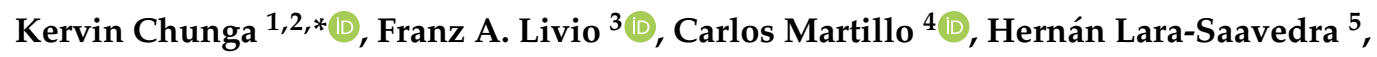 \\ Maria Francesca Ferrario ${ }^{3}(\mathbb{D})$, Ivan Zevallos ${ }^{1}$ and Alessandro Maria Michetti ${ }^{3}$ (D) \\ 1 Facultad de Ciencias Matemáticas, Físicas y Químicas, Carrera de Ingeniería Civil, \\ Universidad Técnica de Manabí (UTM), Avenue José María Urbina, Portoviejo 130111, Ecuador \\ 2 Facultad de Ciencias de la Ingeniería, Universidad Estatal Península de Santa Elena, Km 1 vía principal, \\ La Libertad 240350, Ecuador \\ 3 Dipartimento di Scienza e Alta Tecnologia, Università degli Studi dell'Insubria, Via Valleggio 11, \\ 22100 Como, Italy \\ 4 Grupo de Investigación en Geociencias Marinas y Costeras (GEMAC-FIMCM-FICT), Escuela Superior \\ Politécnica del Litoral, Campus Gustavo Galindo, Km 30.5 vía Perimetral, Guayaquil 09015863, Ecuador \\ 5 Facultad de Ciencias Naturales, Universidad de Guayaquil, Av. Raúl Gómez Lince s/n y Av. \\ Juan Tanca Marengo, Guayaquil 090150, Ecuador \\ * Correspondence: kchunga@utm.edu.ec
}

Received: 9 August 2019; Accepted: 19 August 2019; Published: 26 August 2019

check for updates

\begin{abstract}
We provide a dataset of the landslides induced by the 2016 Pedernales megathrust earthquake, Ecuador (Mw 7.8, focal depth of $20 \mathrm{~km}$ ) and compare their spatial distribution with mapped bedrock lithology, horizontal peak ground acceleration (PGA-h) and the macroseismic intensity based on earthquake-induced environmental effects (ESI-07). We studied 192 coseismic landslides (classified as coherent, disrupted and lateral spreads) located in the epicentral area, defined by the VII to IX $\mathrm{ESI}_{-07}$ isoseismals. Based on our findings, lahar deposits, tuffs and volcanoclastic units are the most susceptible to landslides occurrence. Alluvial plains with fluvial loose fine sand are the most susceptible setting for lateral spreading, with a maximum intensity of IX ESI-07. The coherent landslides are frequently found in altered shale and siltstone geological units with moderate slopes $\left(8^{\circ}-16^{\circ}\right)$, with typical intensity ranging between VII and VIII $\mathrm{ESI}_{-07}$. Our analysis draws a typical framework for slope movements triggered by subduction earthquakes in Ecuador. The most dangerous setting is the coastal region, a relatively highly urbanized area located near the epicenter and where liquefaction can trigger massive lateral spreading events. Coherent and disrupted landslides, dominating the more internal hilly region, can be triggered also in moderate slope settings (i.e., less than $10^{\circ}$ ). Indeed, the regression analysis between seismic intensity, PGA-h and landslide occurrence shows that most of the events occurred at PGA-h values between $0.4 \mathrm{~g}$ and $1.2 \mathrm{~g}$, at a distance of 30 to $50 \mathrm{~km}$ from the rupture plane. Our database suggests that lithology and hillslope geometry are the main geological/geomorphological factors controlling coseismic landslides occurrence; while the distance from the rupture plane plays a significant role on determining the landslide size. Finally, we underline that coseismically-triggered landslides are among the most common environmental effects occurring during large subduction events that can be effectively used to properly evaluate the earthquake macroseismic field. The landslide inventory we compiled is suitable for assessing the vulnerability of physical environment from subduction earthquakes in Ecuador, and offers a primary data source for future worldwide analysis.
\end{abstract}

Keywords: coseismic landslides; macroseismic intensity; ESI-07 scale; Pedernales earthquake; Ecuador 


\section{Introduction}

Among all earthquake-induced environmental effects (sensu [1,2]), landslides are the most widespread and surveyed along coastal areas, in intermontane basins and in hilly areas [1,3-9]. Landslide susceptibility is related to lithologic and geomorphic characteristics including highly weathered loose soils, topographic conditions, local hydrogeological and geological setting (e.g., [3,10]). The geological and geotechnical variables play a key role as predisposing factors to earthquake-induced landslides in active tectonic settings such as the Ecuadorian coast region. Large intraslab and megathrust earthquakes due to the convergence between the Nazca, South American and the Caribbean plates (Figure 1) occur in this area. However, there is a lack of information about earthquake-triggered landslides connected to subduction earthquakes in Ecuador (e.g., [11-13]). Some earthquake-triggered landslides due to upper-plate events (in the order of Mw 6-7), in the northern Ecuadorian Andes, have been described in detail, whilst less is known about the distribution of earthquake-triggered landslides due to large subduction events [14-19].

We present a co-seismic landslide inventory for the 2016 Pedernales earthquake sequence. The earthquake sequence started with a foreshock (ML 5.7, at 18:47), some 10 minutes prior the Mw 7.8 mainshock, that occurred at 18:59 on the April 16, 2016 [20], see Data and Resources; Figure 2a). The extent of physical and environmental damage encompassed an area of thousands of square kilometers [21,22]. Locally, building damage and geological ground effects were enhanced by site amplification due to class $\mathrm{E}$ and $\mathrm{F}$ water saturated soils [23].

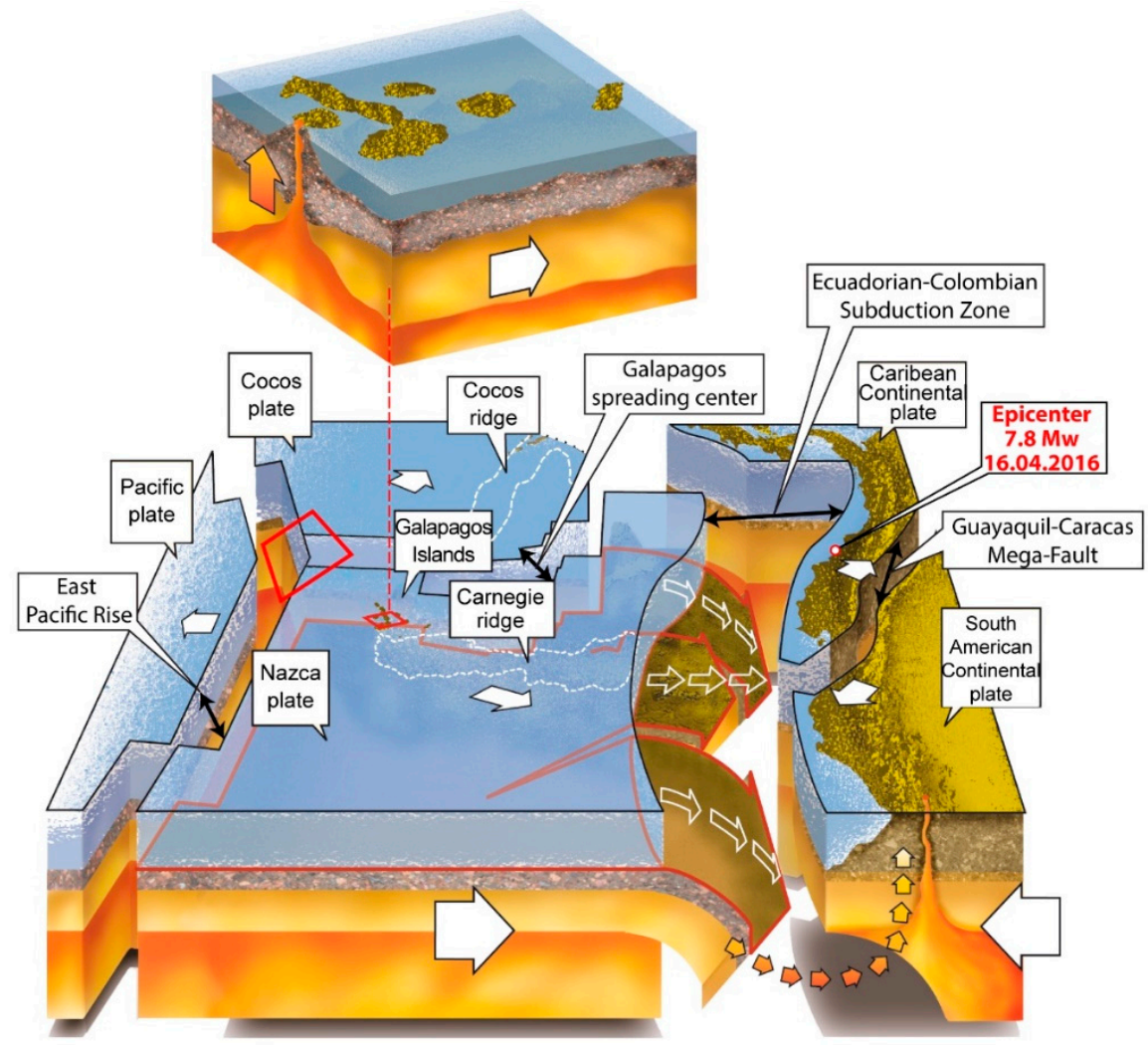

Figure 1. Geodynamic setting of Ecuador, the Galapagos Islands and the Carnegie Ridge; modified after [25].

The epicentral area includes the city of Pedernales and surrounding communities (i.e., Coaque, Jama and Canoa), reaching a maximum intensity of IX $\mathrm{ESI}_{\mathrm{ES}-07}$, assessed from field observation of coastal uplift, soil liquefaction, sinkholes, landslides of natural and stabilized slopes, cracks in natural soils, minor fractures, failure along both the major and minor axis in pavement, particularly asphalt and concrete roads [22]. Coseismic geological effects were observed also across communities near 
Cojimíes (north of the epicenter, Figure 2b) and near Portoviejo (south of the epicenter, Figure 2b),

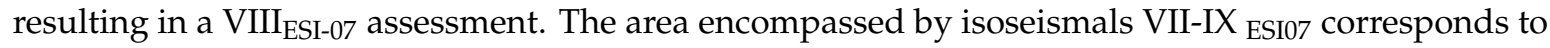
the deformed areas recognized from radar interferometry analysis (e.g., [24]).

Lithology, slope angle, ESI-07 intensity, and PGA-h (horizontal Peak Ground Acceleration, based on information available by the IGEPN; see Data and Resources) are the seismological and geological factors considered in this study to evaluate the hazard of earthquake-triggered landslides. These factors have been analyzed and spatially correlated with the distribution of the coherent, disrupted and lateral spreading landslides in a GIS environment.

We present the outcome of this study together with landslide hazard maps, describing the characteristics of the surveyed landslides and providing new insights into the controlling factors of coseismic landslides during large subduction earthquakes.
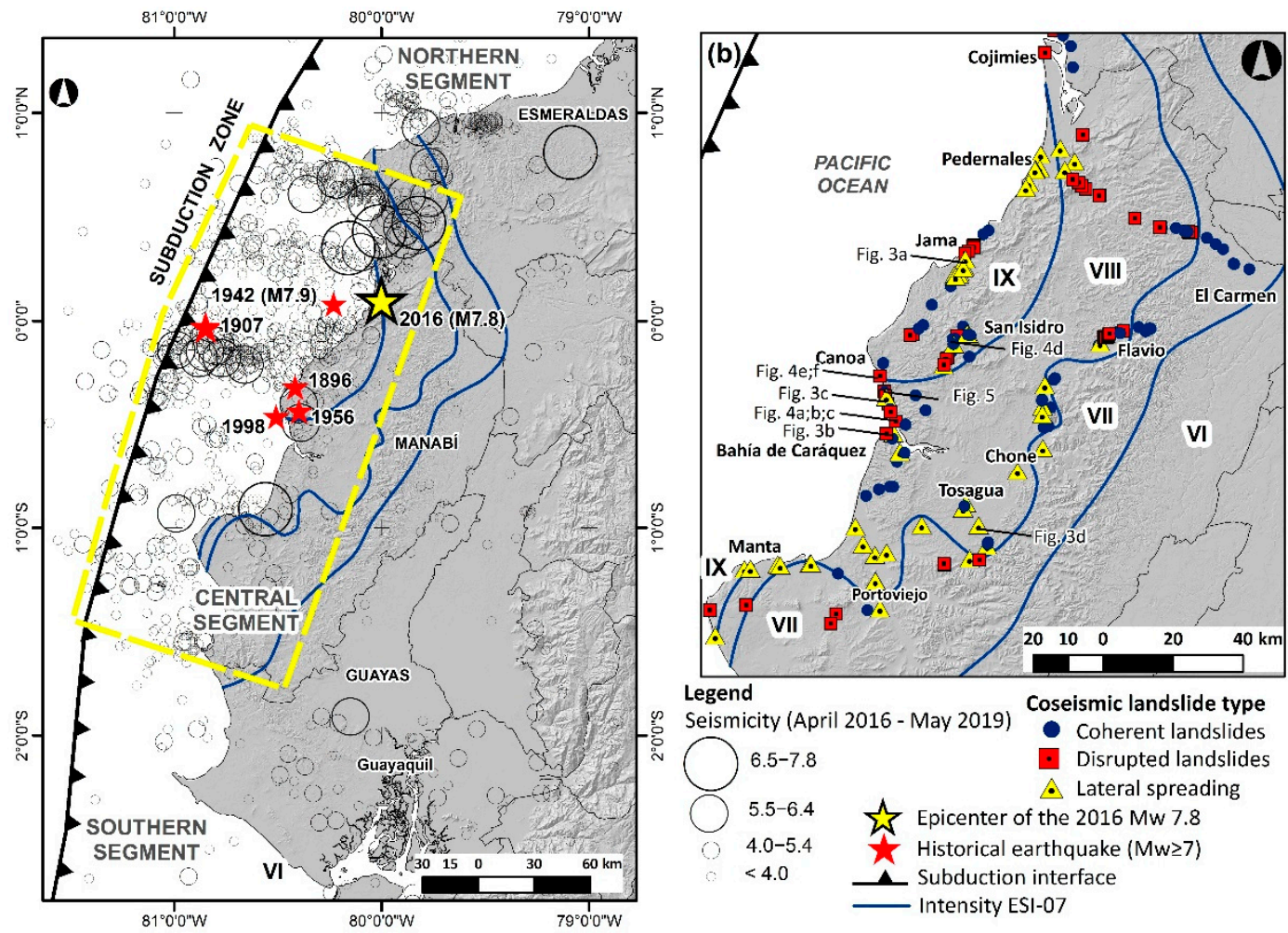

Figure 2. Location maps and seismotectonic setting: a) regional view of central tectonic segment of Ecuador coastal region (yellow dashed box): the epicenters of large subduction events occurred offshore the Manabí province (red stars) and the spatial distribution of aftershocks from the 16th April 2016 to 30th May 2019 are reported; b) earthquake-triggered landslides accompanying the 2016 Pedernales earthquake, dots mark the types of coseismic landslides and blue lines mark the ESI-07 isoseismals as defined by [22]; the location of the photographic documentation in Figures 3 and 4 is also reported.

\section{Description of the Study Area}

The epicentral area of the 2016 Pedernales earthquake sequence is located on the central coast of mainland Ecuador. The mapped area covers about $18,000 \mathrm{~km}^{2}$ of narrow valleys in a hilly landscape, uplifted marine terraces and alluvial plains.

Due to its geomorphological setting, many of the hydrographic basins of the province of Manabí are characterized by alternating periods of erosion and enhanced sedimentation and are typically covered by Quaternary loose sediments. In the eastern sector of the study area, large alluvial fans are the main sedimentary source.

The epicentral area is dominated by altitudes lower than $800 \mathrm{~m}$ a.s.l. Based on the Koppen climate classification [26], the study region is characterized by different sub-climates ranging from tropical 
Monsoon to dry and tropical Savanna [27]. Annual rainfall for the dry climate zone in southernmost Manabí region is less than $500 \mathrm{~mm}$, measured between January and April, while the summer is very dry and hot. Annual rainfall ranges from 500 to $1000 \mathrm{~mm}$ for the tropical Savanna sub-climate where low rainfall occurs between June and November. The tropical Monsoon sub-climate in northernmost Manabí, is as hot as dry, but includes also a dry season from June to November with an annual total rainfall ranging between 1000 and $2000 \mathrm{~mm}$. The predominant vegetation is a dry to very dry tropical forest, followed by mountains with tropical thorn shrub and premontane thorn shrub $[26,28,29]$. The most populated urban areas (i.e., the cities of Manta, Portoviejo, Chone, Bahía de Caráquez, Jama and Pedernales) have been settled on floodplains, alluvial terraces and colluvium-alluvium, where low-resistance soft soils prevail as well as soft rocks of claystone and siltstones, and sandstones in a lesser proportion.

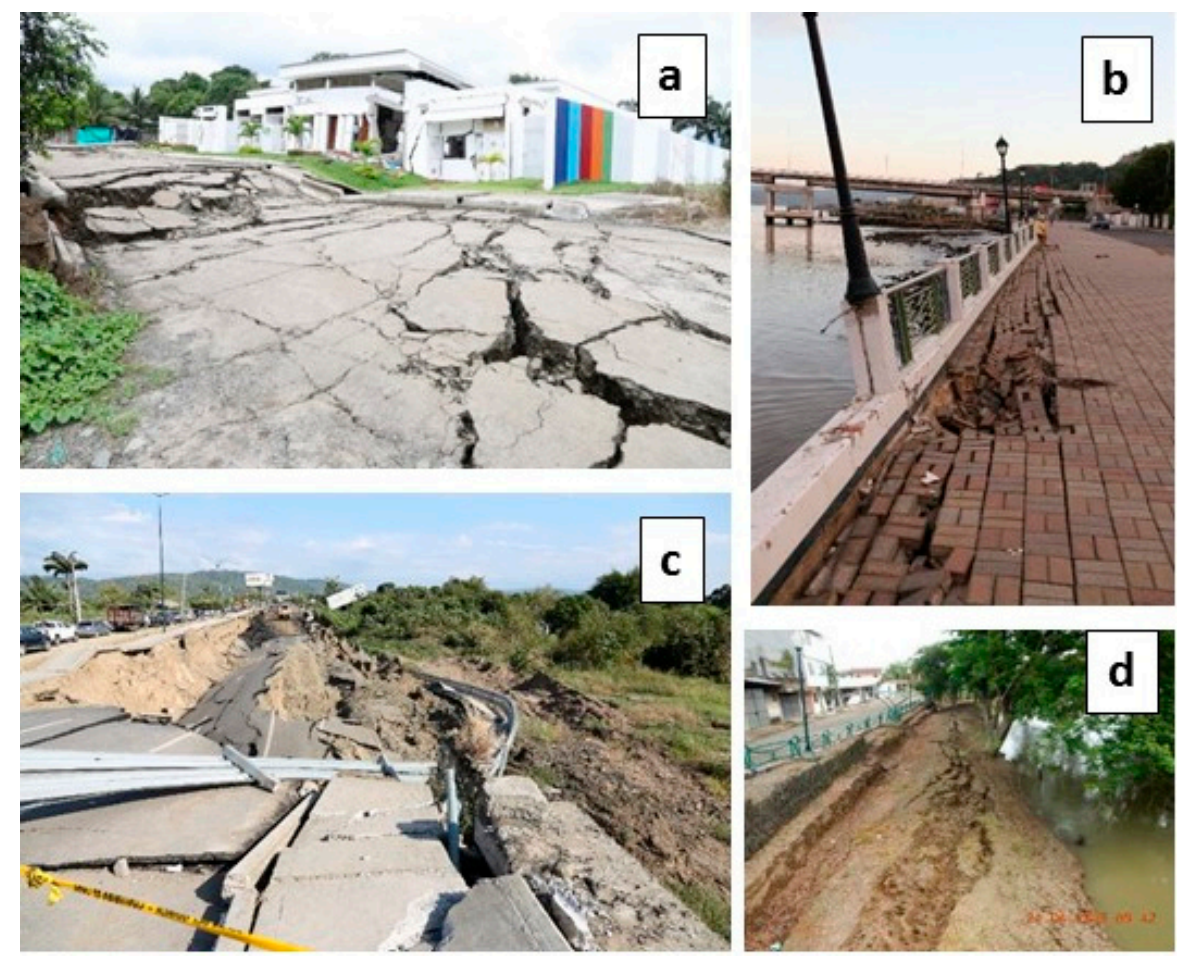

Figure 3. Example of mapped lateral spread landslides: a) deformation in alluvial plain at Jama site, the road is completely displaced for tens of meters, severe damage affected the local kindergarten (IX $\mathrm{ESI}_{\mathrm{E}-07)}$; b) deformations in river bank due to lateral spreading: soil cracks $20 \mathrm{~cm}$ wide at Bahía de Caráquez city (VII $\mathrm{ESI}_{-07)}$; c) total collapse of Mejía bridge at Briceño: lateral spreading, river diversion and changes of fluvial dynamics, damage on house sited on the river side (IX ESI-07); d) lateral spreading in river bank at Calceta city: soil cracks in natural soil 20 to $25 \mathrm{~cm}$ wide, wavy deformations of cobbles, (VII $\left.\mathrm{ESI}_{-07}\right)$; locations on Figure 2.

\section{Seismotectonic Setting and the 2016 Pedernales Earthquake Sequence}

The Ecuadorian coastal region is within an active plate margin where the oceanic Nazca plate subducts the South American continent (e.g., [30-34]). The Nazca plate carries the Carnegie Ridge, which is a mountain range of seamounts resulting from the Galápagos hotspot volcanism (Figure 1; [35]). The subduction of this submarine ridge, which has an average elevation rise up to $2.5 \mathrm{~km}$, has influenced the geodynamics of the coastal zone of Ecuador [36,37], as well as in its coastal geomorphology [38,39] and seismogenic characteristics [36,40-47].

Historically, the 1942 Jama (Mw 7.9) and the 2016 Pedernales (Mw 7.8) earthquakes are the largest subduction earthquakes recorded in the central segment of the subduction interface zone (Figure 2a; $[48,49])$. This tectonic segment registered several megathrust earthquakes, including: 
i) the May 3, 1896, Mw 7.1; ii) the 1 June 1907, Mw 7.4; iii) the 16 January 1956, Mw 7.4 and iv) the Mw 7.1 on August 4, 1998 earthquakes (Figure 2, [22,50]).

The spatial distribution of the April 16, 2016 Pedernales earthquake sequence indicates a rupture zone ca. 100 to $120 \mathrm{~km}$ long [22,24]. The mainshock was located onshore, being less than $10 \mathrm{~km}$ northeast from the city of Pedernales, with a hypocentral depth of $21 \mathrm{~km}$ (source USGS, see Data and Resources). The focal mechanism obtained by IGEPN indicates a low-angle reverse-fault dipping N119/15. Peak ground acceleration up to $1.4 \mathrm{~g}$ was recorded in Pedernales, $0.52 \mathrm{~g}$ in Manta, $0.38 \mathrm{~g}$ in Portoviejo, $0.23 \mathrm{~g}$ in Chone, and $0.19 \mathrm{~g}$ in the Esmeraldas (IGEPN, see Data and Resources). The sequence included more than 3500 aftershocks, the most severe ones occurred on May 18, 2016 with Mw 6.7 to 6.9 [22,51] and some 14 months later with a ML 6.3 (IGEPN, see Data and Resources).
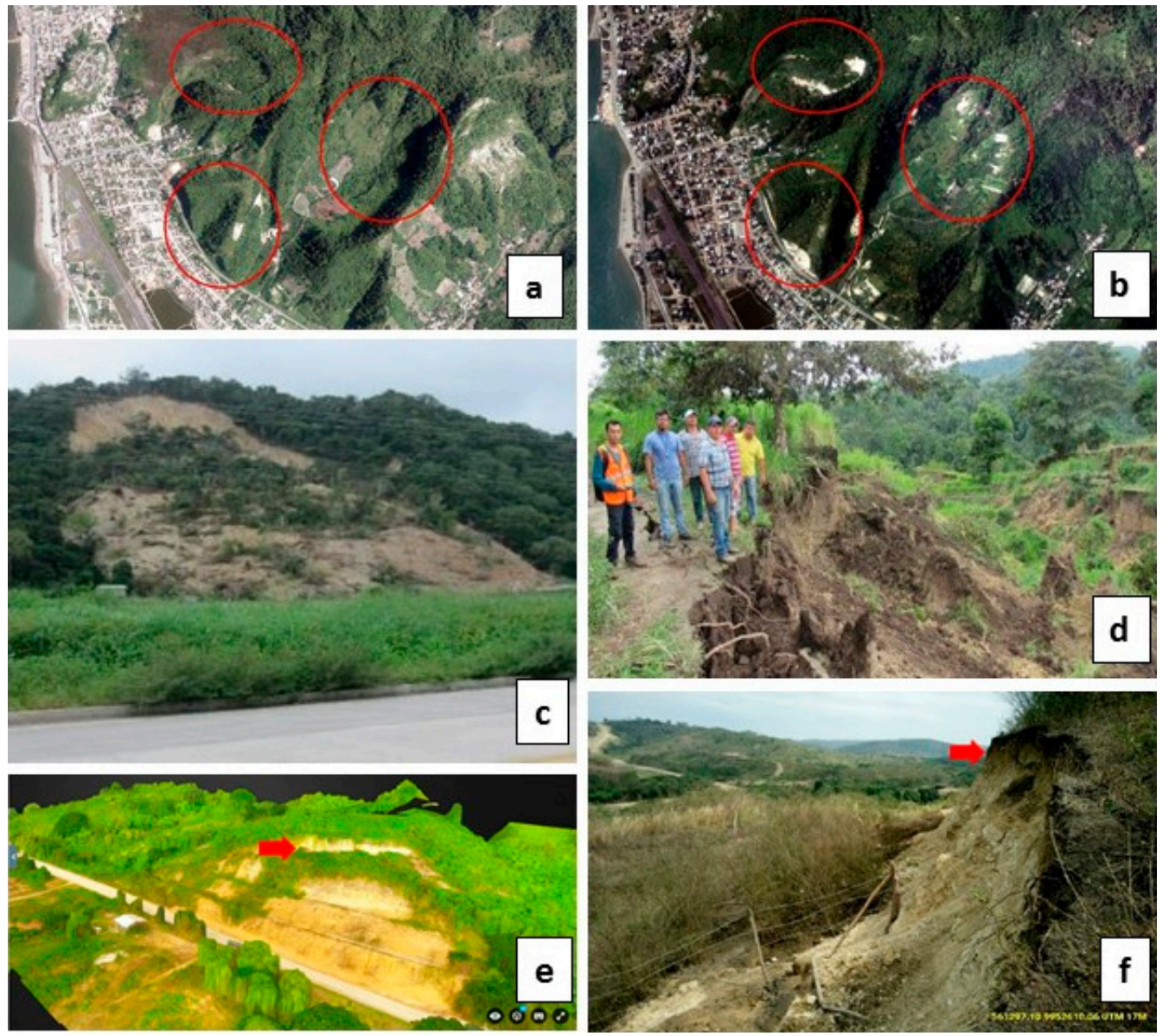

Figure 4. Example of coherent landslides: a) and b) pre- and post-earthquake satellite imagery at San Vicente, provided by the Web-GIS of the Military Geographical Institute of Ecuador (IGM) (VIII ESI-07); c) rotational landslide at Briceño site, volume less than $3200 \mathrm{~m}^{3}$, tree cover fall, active slope (VIII $\mathrm{ESI}_{-07}$ ); d) rotational landslide at San Isidro, soil cracks 10 to 20 meters wide in soil, rotational landslides ca. $60 \mathrm{~m}$ long (IX ESI-07); e) and f) stabilized slope also reported damage in the epicentral area, northern of Canoa site, where part of the hillslope was displaced by landslide of ca. $400 \mathrm{~m}^{3}$ (drone imagery courtesy of by Global Medic and Servicio Nacional de Gestión de Riesgo y Emergencias de Ecuador),

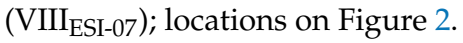

This sector of the subduction zone, including the entire province of Manabí, has a short seismic record covering the last 120 years that suggests a recurrence interval of approximately 20 years for $\mathrm{Mw}>7.0$ events, and between 70 and 80 years for $\mathrm{Mw}>7.5$ [22,52]. Such subduction-related earthquakes have a recurrence relatively short in comparison with the subduction zones north and south of it [22]. 


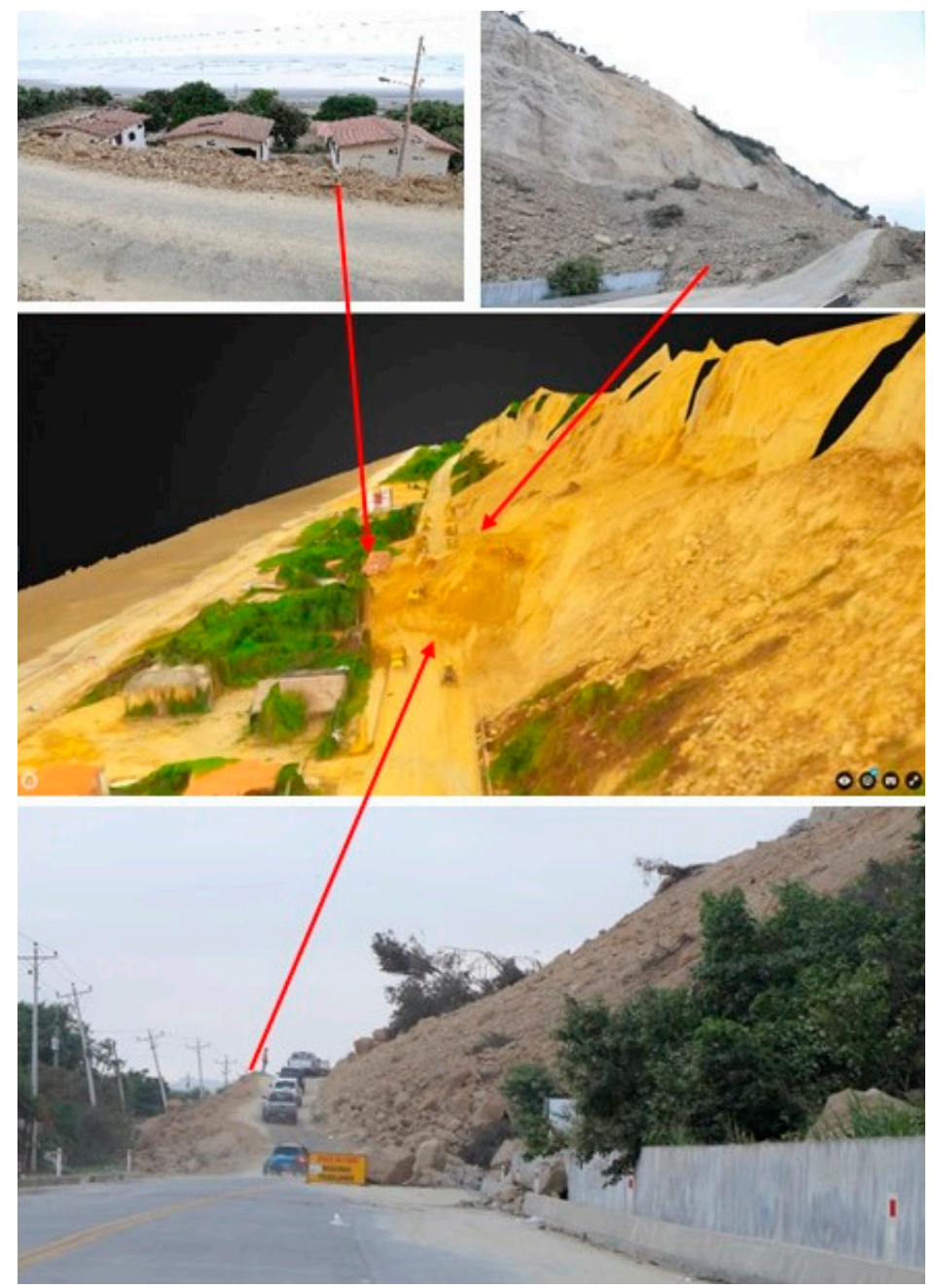

Figure 5. Example of disrupted landslide at Briceño: rock fall and debris displacement, fractured slopes, completely destroyed road, house damaged by landslide, volume ca $10.000 \mathrm{~m}^{3}$ (VIII $\mathrm{ESI}_{-07}$ ); courtesy of drone imagery by Global Medic and Servicio Nacional de Gestión de Riesgo y Emergencias de Ecuador; locations on Figure 2.

\section{Methods and Materials}

Shortly after the mainshock, we mapped in the field all the observable earthquake-induced environmental effects (sensu, [1]), accessible through the main access roads and towns near Pedernales, which is the location of the instrumental epicenter where the peak ground acceleration of $1.4 \mathrm{~g}$ was recorded (IGEPN Accelerograph Ecuadorian Network; see Data and Resources). Government institutions such as MTOP (i.e., Ministerio de Transporte y Obras Pública) and MIDUVI (i.e., Ministerio de Desarrollo Urbano y Vivienda) provided logistics and transportation management due to partial destruction of the main access roads to towns, bridges and buildings by creating fieldwork camp sites for geotechnical engineers and geologists reaching out to the entire Manabí province and the southern part of Esmeraldas province.

Preliminary field mapping evaluated the macroseismic intensities of the primary coseismic geological effects (i.e., coastline uplifting along beaches and cliffs; e.g., [22,53] and secondary effects (i.e., soil liquefaction causing lateral spreading, subsidence, sinkhole and sand boils, as well as cracks in the soil, pavement failure in asphalt roads as well as landslides in stable and unstable slopes), using the ESI-07 intensity scale, with values ranging from VII to IX $\mathrm{ESI}_{-07}$ in a coseismic affected area of about $18,000 \mathrm{~km}^{2}$ [21,22]. Along with this database, an inventory of 192 seismically induced landslides 
(in attached pertinent (E) electronic supplement to this article) by the $2016 \mathrm{Mw} 7.8$ event is herein provided (Figure 2), grouping them as follows:

(a) lateral spreads, landslides which moved in a translational mode in areas of liquefied gravel, sand, or silt, or rarely in sensitive clay transformed into fluid by disturbance [3,54], out of which 58 coseismic landslides were surveyed (Figure 3);

(b) coherent landslides, generally deep-seated, consisting of one or multiple blocks sliding on planar or smoothly curved basal shear surfaces, out of which 78 landslides in the epicentral area were surveyed (Figure 4);

(c) disrupted landslides associated with rock falls, rock slides, soil falls and disrupted soil slide, adding up to 56 surveyed coseismic effects, between earthquake-induced landslides and reactivated older landslides (Figure 5).

In this study, we also manually digitized some landslides on satellite imagery (SPOT-CNES imagery, courtesy of Google Earth) to i) check the extent of landslides at some of the surveyed events, ii) assure that no pre-earthquake landslides were present and iii) check field-observed mapping, in the closeness of some surveyed sites, especially in remote areas where only limited access was possible (Figure 4). Moreover, we checked the coseismic landslide inventory provided by the British Geological Survey BGS and GEER- ATC (see Data and Resources), referred only to the areas of Portoviejo, Bahía de Caráquez, Chone, Muisne and Crucita. This resulted in a statistically significant database of earthquake-induced landslides, though not comprehensive over the entire area interested by coseismic slope movements.

We compared the landslide occurrence with a set of selected variables that can possibly be considered as triggering or predisposing factors: lithology type, horizontal peak ground acceleration (PGA-h), topographic slope (derived from the 1 arc second SRTM digital elevation model) and distance from both the epicenter and the subduction rupture plane.

We derived the statistical correlation of landslide occurrence for each class of variables (i.e., PGA-h and lithology) using a statistical approach, modified after the Information Value Method (InfoVAL). The method allows the quantified prediction of susceptibility by means of a score (Wi), calculated according to landslide occurrence on each class, weighed according to the class distribution over the entire study area:

$$
W i=\ln \frac{\text { Densclass }_{i}}{\text { Densmap }_{i}}
$$

where $W i$ is the score for the $i^{\text {th }}$ class, Densclass is the landslide occurrence for the $i^{t h}$ class and Desnmap is the $i^{\text {th }}$ class occurrence on the whole area. This formula normalizes the event occurrences over the spatial distribution of each considered class: positive values indicate positive statistical correlation, negative values a negative one, while values close to zero indicate a random distribution of the data.

Since we did not map the areal extent of landslides and considering that the survey coverage was limited by site accessibility, we adopted simple univariate statistics for the description of topographic slope intervals typically associated with each landslide category.

We calculated the distance of each event from both the mainshock location (i.e., epicentral distance) and from the seismogenetic rupture plane. The latter has been calculated considering a rupture plane orientation on N119/15, as derived from seismological data and the distance have been calculated as the closest distance to the plane (i.e., Rrup distance).

\section{Results and Discussion}

Most landslides have shallow shear planes, between 2 and $4 \mathrm{~m}$ depth. On the contrary, few landslides have deep rupture planes (up to 15-30 m below ground level), as documented in the Briceño and San Isidro sites. A large number of landslides fall in the range of 200 to $3200 \mathrm{~m}^{3}$ (VIII $\mathrm{ESI}_{-07}$ ), while only few of them fall in the range of 5000 to $8000 \mathrm{~m}^{3}$ (marked as intensity IX $\mathrm{ESI}_{-07}$ ). Isolated rotational landslides and rockfalls smaller than $200 \mathrm{~m}^{3}$ are regarded as intensity $\mathrm{VII}_{\mathrm{ESI}-07}$ (southern part of Esmeraldas province). Landslides located in plains and alluvial terraces are 
constrained to low resistance cohesive soils and are mainly lateral propagations caused by liquefaction. The earthquake-induced landslides extend as far as to the southern Manabí province, $134 \mathrm{~km}$ away from the instrumental epicenter, where lateral-spreading displacements was recorded near the city of Portoviejo in a site within the VIII $\mathrm{ESI}_{-07}$ and where $0.35 \mathrm{~g}$ of PGA-h was recorded.

According to the geological map at a scale of 1:500,000 of the coasts of Ecuador [55], we divided the study area into 5 lithological units (Figure 6): loose fluvial deposits and/or fine to coarse grained coastal units (AL); mainly sandstones and conglomerates (SS); shales, siltstones and mudstones (SS); tuffs and volcanoclastic deposits (VV); mainly basalts, hyaloclastite and associated greywackes (BB).

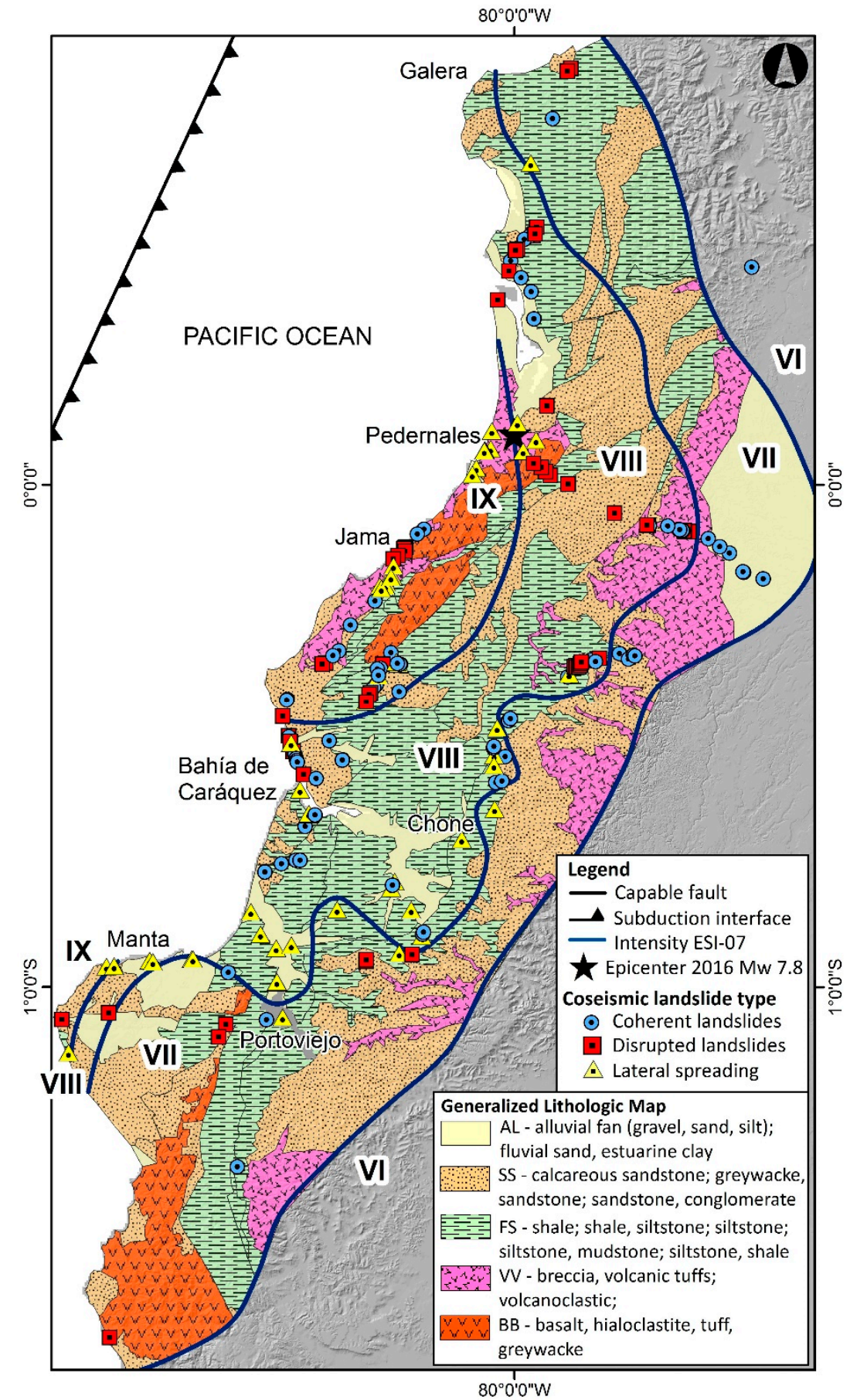

Figure 6. Simplified geologic map (modified from [55]) of the area comprised between isoseismals VII and IX $\mathrm{ESI}_{\mathrm{E} 7}$. 
Our analysis shows that tuffs and volcanoclastic units recorded the largest number of coseismic landslides. Shales and siltstones host most coherent landslides while sandstones are mostly associated with disrupted landslides. Fluvial loose deposits and alluvial plains constitute the most susceptible setting for lateral spreading (Figure 7).

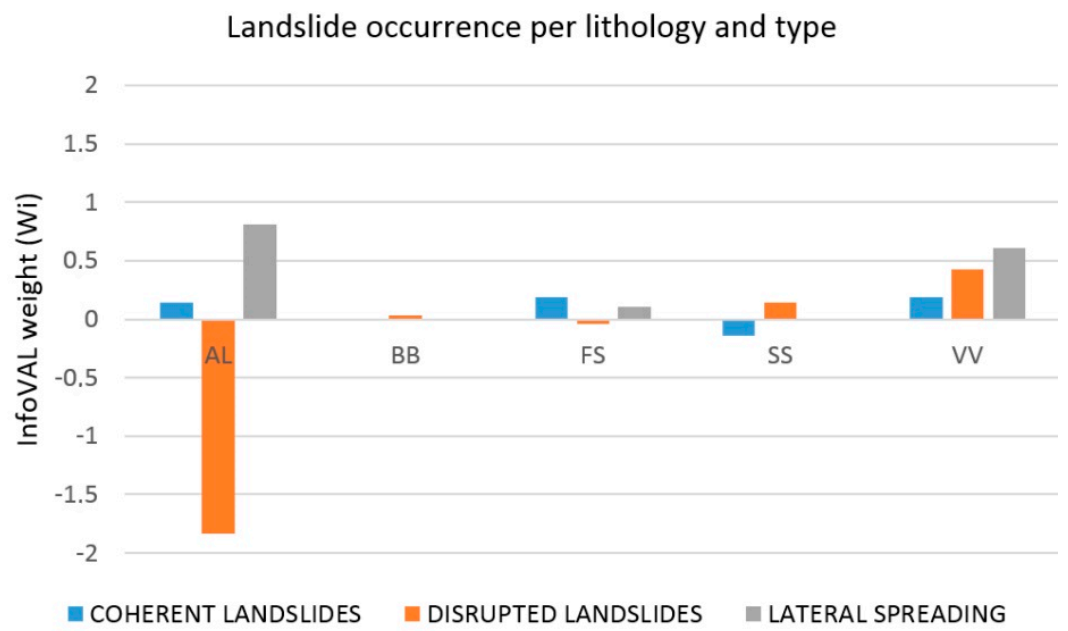

Figure 7. Statistical correlation between landslide occurrence and lithology type; correlation is expressed as an InfoVAL weight (Wi), where positive values indicate a statistically significant correlation (see methods for further details); lithology codes are the same as in Figure 6.

Lateral-spreading landslides are located in plains and alluvial terraces as well as few inclined slopes (Figure 3). Coherent landslides are located on moderate slopes with inclination between $8^{\circ}$ and $16^{\circ}$ and are mostly developed in Pliocene and Pleistocene geological units, which are composed of volcanic units and highly weathered clastic rocks. Disrupted landslides are developed on escarpments with inclination ranging from $16^{\circ}$ to $55^{\circ}$, many of which are formed in high relief within the epicentral area as highlighted in Figure 5, where Miocene sandstone and greywacke lithological units (SS) predominate. These results coincide well with those obtained for the coseismic landslides caused by the 2011 Tohoku (Mw 9.0) and the Maule (Mw 8.8) thrust earthquakes, where most landslides, in the epicentral area, occurred in Neogene geological units [56-58].

The seismic intensity and the PGA-h characterize the degree of destruction and the seismic energy of earthquakes [8]. The ESI-07 intensity map is spatially well-correlated with the PGA-h isolines of the Pedernales earthquake (Figure 8 ) and shows a distribution of the intensity VII to IX $\mathrm{ESIO7}_{\text {contours }}$ elongated along the with the rupture strike and encompassing the area affected by earthquake-triggered landslides. The isoseismal zone of $\mathrm{VI}_{\mathrm{ESI}-07}$ has much fewer landslides, with volumes lower than ca. $10^{3} \mathrm{~m}^{3}$, especially where the slope is unstable and particularly steep.

For the area encompassing the ruptured sector we can estimate a relationship between ESI-07 degree and the PGA-h: IX $\mathrm{ESI}_{-07}$ ranges between $0.73 \mathrm{~g}$ and $1.35 \mathrm{~g}$; VII ESI-07 from $0.55 \mathrm{~g}$ to $0.73 \mathrm{~g}$ and VII $\mathrm{ESI}_{-07}$ from $0.30 \mathrm{~g}$ to $0.55 \mathrm{~g}$.

The number of landslide events and their size can be scaled with the epicentral distance up to VIII $_{\text {ESI-07 }}$ (Figures 9 and 10, Supplementary Materials). Several landslides ascribable to IX $\mathrm{ESI}_{-07}$ have been mapped in the coastal region but these are mainly lateral spreads and are more influenced by the local geomorphological and geological setting (i.e., coverage lithology and thickness, depth of the aquifer etc.) than by distance or other factors (Figure 11). Collectively, the coseismic landslides caused by the Pedernales earthquake (Mw 7.8) are strongly dependent from the distance to the rupture plane and PGA-h. Most of the landslides are triggered for values that are bounded between $0.4 \mathrm{~g}$ and $1.2 \mathrm{~g}$ and within a Rrup distance of less than $50 \mathrm{~km}$ (Figure 9, Supplementary Materials). 


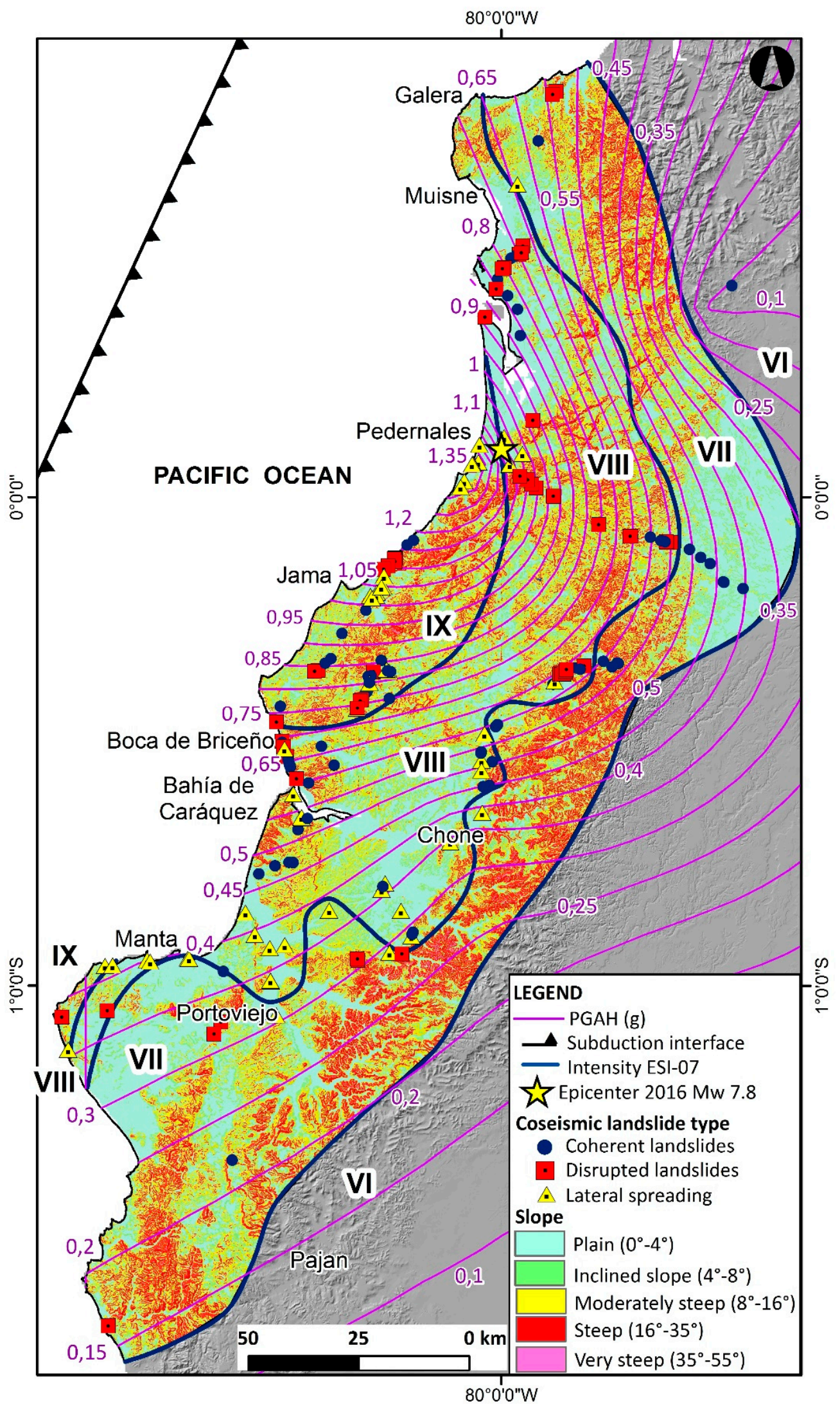

Figure 8. Simplified slope map and PGA-h isolines in the area of 2016 coseismic landslide inventory. 

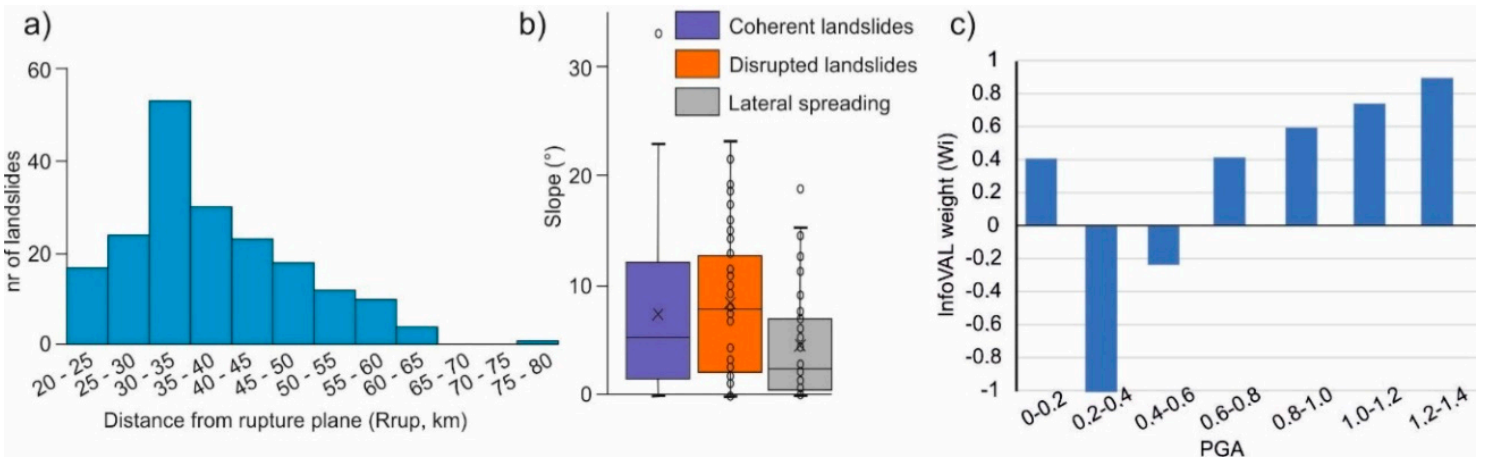

Figure 9. Landslides occurrence per (a) distance from the rupture plane (Rrup), (b) slope values and c) InfoVAL weights for PGA-h values.

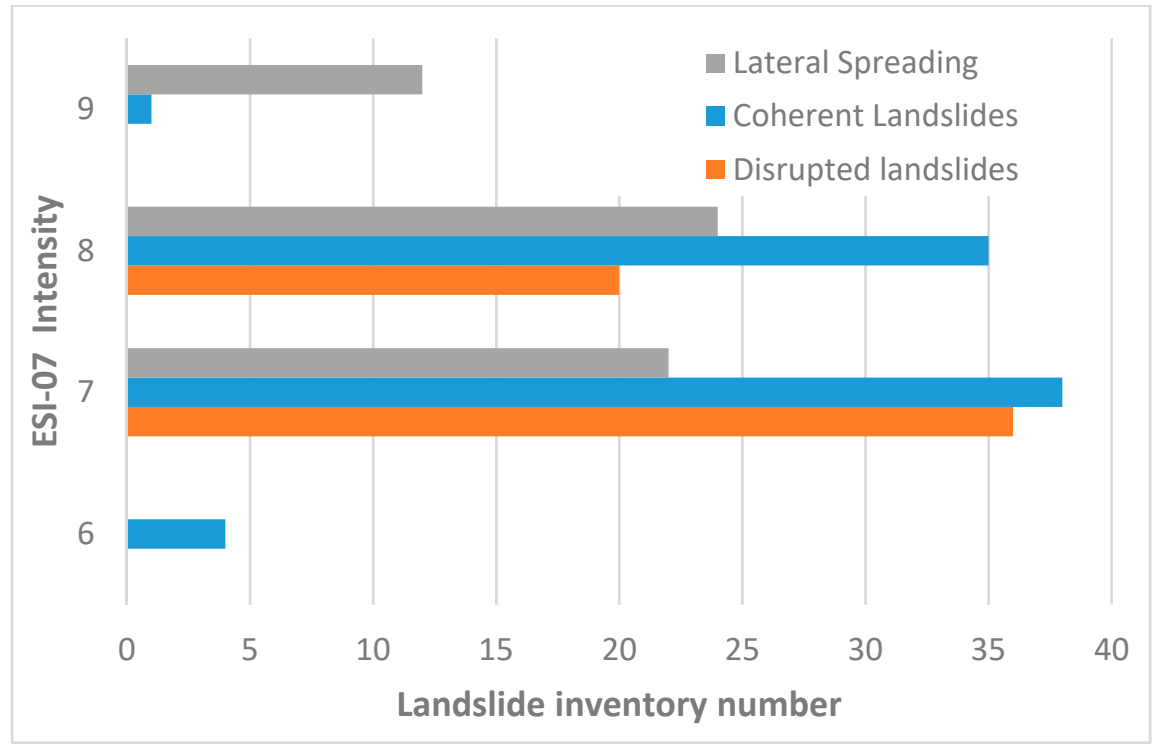

Figure 10. Distribution of coseismic landslides types as a function of assessed ESI-07 macroseismic intensity.
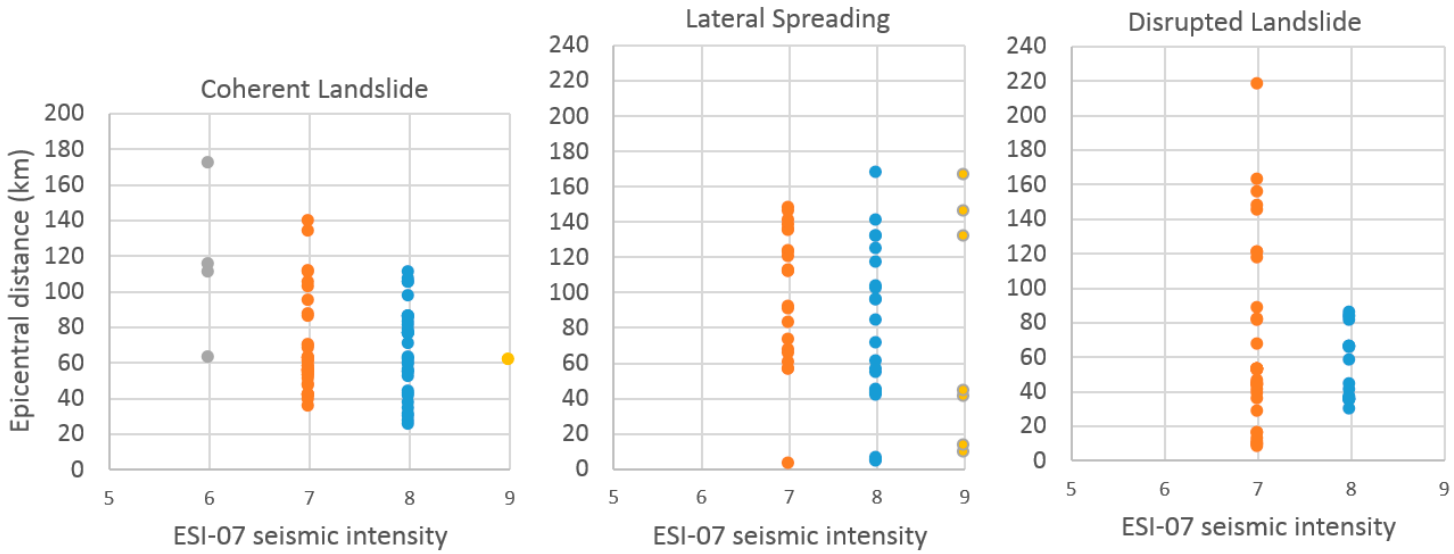

Figure 11. Relationship between epicentral distance, landslide types and ESI-07 seismic intensity.

\section{Conclusions}

With this first database, we produced an inventory of 192 seismically-induced landslides related to the 2016 Pedernales earthquake (Mw 7.8). Landslides were analyzed through a bivariate approach against: slope, lithological setting, PGA-h and macroseismic intensity data. 
The spatial distribution of PGA-h, ranging between $0.4 \mathrm{~g}$ and $1.2 \mathrm{~g}$, is consistent with the maximum VII-IX ESI-07, recorded over an area of about $18,000 \mathrm{~km}^{2}$. The disrupted landslide type is preferably located on fractured greywacke/sandstone units and in high relief areas, with slopes ranging between $16^{\circ}$ and $55^{\circ}$. Our database suggests that lithology and hillslope geometry are the main geological/geomorphological factors controlling coseismic landslides occurrence; while the distance from the rupture plane plays a significant role on determining the landslide size. Indeed, the regression analysis between seismic intensity, PGA-h and landslide occurrence shows that most of the events occurred at PGA-h values between $0.4 \mathrm{~g}$ and $1.2 \mathrm{~g}$, at a distance of 30 to $50 \mathrm{~km}$ from the rupture plane.

Our analysis draws a typical framework for slope movements triggered by subduction earthquakes in Ecuador. The most dangerous setting is the coastal region, a relatively highly urbanized area located near the epicenter and where liquefaction can trigger massive lateral spreading events. Coherent and disrupted landslides, dominating the more internal hilly region, can be triggered also in moderate slope settings (i.e., less than $10^{\circ}$ ).

We highlight that both the dimensions and frequency of landslides scale with distance in accordance with PGA-h and earthquake intensity (ESI-07) and through macroseismic intensity scenarios or strong motion modeling (e.g., USGS SHAKE maps) this information can be effectively used for the prediction of landslides distribution following strong subduction events. Calculated regressions can be considered valid for the South American subduction setting only, still the proposed approach can also be exported in different seismotectonic settings worldwide.

We note that timely field mapping after the mainshock allows to calibrate with unprecedented accuracy the geographic distribution of earthquake environmental effects, specifically landslides; and to understand the factors which control their distribution. We remark that coseismically-triggered landslides are among the most common environmental effects occurring during large subduction events. This effectively augment the relevance of coseismic landslide investigations for properly evaluating the earthquake macroseismic field, as initially suggested by the pioneers in the study of seismic intensity (e.g., [59-62]. We argue that our results represent a clear illustration of this point.

Data and Resources: Seismicity and macroseismic data were collected from IGEPN (http://www.igepn.edu.ec/servicios/eq20160416, last accessed June 2019);

USGS (http://earthquake.usgs.gov/earthquakes/eventpage/us20005j32\#dyfi, last accessed May 2019) and the Geological Survey of Colombia (http://studylib.es/doc/6527439/informe-del-sismo-del16-de-abril-de-2016-en, last accessed June 2019).

The isoseismal map for EMS-98 intensity realized by IGEPN is available at http://www.igepn.edu. ec/servicios/noticias/1324-informe-sismico-especial-n-18-2016 (last accessed May 2019).

Additional information on the Pedernales earthquake made available by BGS (British Geological Survey) and GEER-ATC was obtained at https://www.bgs.ac.uk/research/earthHazards/epom/ ecuadorEarthquake.html (last accessed June 2019) and http://www.geerassociation.org/administrator/ components/com_geer_reports/geerfiles/ECUADOR_Report_GEER-049-v1b.pdf (last accessed May 2019), respectively.

The DTM used for analysis is the NASA SRTM 3.0 global model, 1 arc second resolution: https://lpdaac.usgs.gov/news/nasa-shuttle-radar-topography-mission-srtm-version-30srtm-plus-product-release/ (last accessed 6 August, 2019).

Some of the figures were realized using Qgis and Arcmap® software.

Supplementary Materials: The following are available online at http://www.mdpi.com/2076-3263/9/9/371/s1, Table S1: Coseismic landslide inventory for the 2016 Pedernales earthquake sequence.

Author Contributions: K.C. and F.A.L. designed the study. C.M., H.L.-S. and I.Z. analysed the geomorphologic features, landslide types and catalogues of earthquakes, M.F.F. processed and analysed the statistical correlation of landslide occurrence. A.M.M. prepared the manuscript with advice and feedback from all team members.

Funding: This research received no external funding.

Acknowledgments: This work was supported by the Geohazard Research Group of the Universidad Técnica de Manabí (UTM). The authors are grateful with the MTOP (Ministerio de Transporte y Obras Publicas) of Ecuador 
for the technical support during field-survey activities and data collection. The authors are also grateful to the anonymous reviewers for the constructive comments that helped in improving this paper.

Conflicts of Interest: The authors wish to confirm that there are no known conflicts of interests associated with this publication. This research did not receive any specific grant from funding agencies in the public, commercial, or not-for-profit sectors.

\section{References}

1. Michetti, A.M.; Esposito, E.; Guerrieri, L.; Porfido, S.; Serva, L.; Tatevossian, R.; Vittori, E.; Audemard, F.; Azuma, T.; Clague, J.; et al. Environmental Seismic Intensity Scale 2007-ESI 2007. In Memorie Descrittive della Carta Geologica d'Italia, 74, 7-54; Servizio Geologico d'Italia-Dipartimento Difesa del Suolo, APAT: Roma, Italy, 2007. Available online: http://www.isprambiente.gov.it/en/publications/technical-periodicals/ descriptive-memories-of-the-geological-map-of/intensity-scale-esi-2007?set_language=en (accessed on 15 August 2019).

2. Serva, L. History of the Environmental Seismic Intensity Scale ESI-07. Geosciences 2019, 9, 210. [CrossRef]

3. Keefer, D.K. Landslides caused by earthquakes. Geol. Soc. Am. Bull. 1984, 95, 406-421. [CrossRef]

4. Harp, E.L.; Jibson, R.W. Landslides triggered by the 1994 Northridge, California, earthquake. Bull. Seismol. Soc. Am. 1996, 86, S319-S332.

5. Berzhinskii, Y.A.; Ordynskaya, A.P.; Gladkov, A.S.; Lunina, O.V.; Berzhinskaya, L.P.; Radziminovich, N.A.; Radziminovich, Y.B.; Imayev, V.S.; Chipizubov, A.V.; Smekalin, O.P. Application of the ESI-2007 scale for estimating the intensity of the Kultuk earthquake, August 27, 2008 (south Baikal). Seism. Instrum. 2010, 46, 307-324. [CrossRef]

6. Delgado, J.; Peláez, J.A.; Tomás, R.; García-Tortosa, F.J.; Alfaro, P.; Casado, C.L. Seismically-induced landslides in the Betic Cordillera (S Spain). Soil Dynam. Earthq. Eng. 2011, 31, 1203-1211. [CrossRef]

7. Serva, L.; Vittori, E.; Comerci, V.; Esposito, E.; Guerrieri, L.; Michetti, A.M.; Mohammadioun, B.; Mohammadioun, G.C.; Porfido, S.; Tatevossian, R.E. Earthquake Hazard and the Environmental Seismic Intensity (ESI) Scale. Pure Appl. Geophys. 2016, 173, 1479-1515. [CrossRef]

8. Xu, C.; Ma, S.; Tan, Z.; Xie, C.; Toda, S.; Huang, X. Landslides triggered by the 2016 Mj 7.3 Kumamoto, Japan, earthquake. Landslides 2018, 15, 551. [CrossRef]

9. Huayong, N.; Hua, G.; Yanchao, G.; Blumetti, A.M.; Comerci, V.; Di Manna, P.; Guerrieri, L.; Vittori, E. Comparison of Earthquake Environmental Effects and ESI intensities for recent seismic events in different tectonic settings: Sichuan (SW China) and Central Apennines (Italy). Eng. Geol. 2019, 258, 105149. [CrossRef]

10. Di Manna, P.; Guerrieri, L.; Piccardi, L.; Vittori, E.; Castaldini, D.; Berlusconi, A.; Bonadeo, L.; Comerci, V.; Ferrario, F.; Gambillara, R.; et al. Ground effects induced by the 2012 seismic sequence in Emilia: Implications for seismic hazard assessment in the Po Plain. Ann. Geophys. 2012, 55, 697-703.

11. Egred, J. Catalogo de Terremotos del Ecuador 1541-2009; Internal Report; Escuela Politecnica Nacional, Instituto Geofisico: Quito, Ecuador, 2009.

12. Chunga, K. Shallow Crustal Earthquakes and Seismic Zonation for Ecuador through the Integration of Geological, Seismological and Morphostructural Data. Ph.D. Thesis, University of Insubria, Varese, Italy, 2010.

13. Chunga, K.; Toulkeridis, T.; Vera-Grunauer, X.; Gutierrez, M.; Cahuana, N.; Alvarez, A. A review of earthquakes and tsunami records and characterization of capable faults on the northwestern coast of Ecuador. J. Sci. Tsunami Hazards 2017, 36, 100-127.

14. Tibaldi, A.; Ferrari, L.; Pasquarè, G. Landslides triggered by earthquakes and their relations with faults and mountain slope geometry: An example from Ecuador. Geomorphology 1995, 11. [CrossRef]

15. Beauval, C.; Yepes, H.; Bakun, W.H.; Egred, J.; Alvarado, A.; Singaucho, J.C. Locations and magnitudes of historical earthquakes in the Sierra of Ecuador (1587-1996). Geophys. J. Int. 2010, 181, 1613-1633. [CrossRef]

16. Beauval, C.; Yepes, H.; Palacios, P.; Segovia, M.; Alvarado, A.; Font, Y.; Aguilar, J.; Troncoso, L.; Vaca, S. An earthquake catalog for seismic hazard assessment in Ecuador. Bull. Seism. Soc. Am. 2013, 103, 773-786. [CrossRef]

17. Crespo, E.; O'Rourke, T.D.; Nyman, K.J. Effects on lifelines. In The March 5, 1987, Ecuador Earthquakes: Mass Wasting \& Socioeconomic Effects; National Research Council: Washington, DC, USA, 1991; Chapter 6. 
18. Gómez-Capera, A.A.; Leschiutta, I. Determining the parameters of earthquake sources in South America from macroseismic intensity data (CERESIS database). Earth Sci. Res. J. 2004, 8, 10.

19. Giesecke, A.; Capera, A.G.; Leschiutta, I.; Migliorini, E.; Valverde, L.R. The CERESIS earthquake catalogue and database of the Andean Region: Background, characteristics and examples of use. Ann. Geophys. 2004, 47. [CrossRef]

20. IGEPN. Instituto Geofísico Escuela Politécnica Nacional. Quito. Available online: http://www.igepn.edu.ec/ solicitud-de-datos (accessed on 10 May 2019).

21. Toulkeridis, T.; Chunga, K.; Rentería, W.; Rodriguez, F.; Mato, F.; Nikolaou, S.; Antonaki, N.; Diaz-Fanas, G.; Besenzon, D. Mw7.8 Muisne, Ecuador 4/16/16 earthquake observations: Geophysical clustering, intensity mapping, tsunami. In Proceedings of the 16th World Conference on Earthquake Engineering, 16WCEE 2017, Santiago, Chile, 9-13 January 2017.

22. Chunga, K.; Livio, F.; Mulas, M.; Ochoa-Cornejo, F.; Besenzon, D.; Ferrario, M.F.; Michetti, A.M. Earthquake ground effects and intensity of the 16 April 2016, Mw 7.8 Pedernales Earthquake (Ecuador): Implications for the source characterization of large subduction earthquakes. Bull. Seismol. Soc. Am. 2018, 108, 3384-3397. [CrossRef]

23. NEC-11. 2015. Norma Ecuatoriana de la Construcción. Registro Oficial No. 413 del 10 de enero de 2015. Available online: http://www.normaconstruccion.ec/ (accessed on 11 April 2019).

24. Nocquet, J.M.; Jarrin, P.; Vallée, M.; Mothes, P.A.; Grandin, R.; Rolandone, F.; Delouis, B.; Yepes, H.; Font, Y.; Fuentes, D.; et al. Supercycle at the Ecuadorian subduction zone revealed after the 2016 Pedernales earthquake. Nat. Geosci. 2016, 10, 145-149. [CrossRef]

25. Toulkeridis, T.; Porras, T.; Tierra, A.; Toulkeridis-Estrella, K.; Cisneros, D.; Luna, M.; Carrión, J.L.; Herrera, M.; Murillo, A.; Perez, J.C.; et al. Two independent real-time precursors of the 7.8 Mw earthquake in Ecuador based on radioactive and geodetic processes-Powerful tools for an early warning system. J. Geodyn. 2019, 126, 12-22. [CrossRef]

26. Pourrut, P. Los Climas del Ecuador: Fundamentos Explicativos. In Los climas del Ecuador; CEDIG: Quito, Ecuador; Institut de recherche pour le développement: Marseille, France, 1983; pp. 7-41.

27. UNESCO. Atlas Pluviométrico del Ecuador; UNESCO: Quito, Ecuador, 2010.

28. Pourrut, P.; Róvere, O.; Romo, I.; Villacrés, H. Clima del Ecuador. In El Agua en el Ecuador: Clima, Precipitaciones, Escorrentía; Institut de recherche pour le développement: Marseille, France, 1995; pp. 13-26.

29. Kottek, M.; Grieser, J.; Beck, C.; Rudolf, B.; Rubel, F. World map of the Köppen-Geiger climate classification updated. Meteorol. Z. 2006, 15, 259-263. [CrossRef]

30. Hey, R. Tectonic evolution of the Cocos-Nazca spreading center. Geol. Soc. Am. Bull. 1977, 88, i-vi. [CrossRef]

31. Lonsdale, P. Ecuadorian subduction system. AAPG Bull. 1978, 62, 2454-2477.

32. Pennington, W.D. Subduction of the eastern Panama Basin and seismotectonics of northwestern South America. J. Geophys. Res. B Solid Earth Planets 1981, 86, 10753-10770. [CrossRef]

33. Eguez, A.; Alvarado, A.; Yepes, H.; Machette, M.N.; Costa, C.; Dart, R.L.; Bradley, L.A. Database and Map of Quaternary Faults and Folds of Ecuador and Its Offshore Regions; Open-File Report 03-289; US Geological Survey: Reston, VA, USA, 2003. Available online: https://pubs.usgs.gov/of/2003/ofr-03-289/ (accessed on 5 March 2019).

34. Veloza, G.; Styron, R.M.; Taylor Mora, A. Open-source archive of active faults for northwest South America. GSA Today 2012, 22, 4-10. [CrossRef]

35. Sallarès, V.; Charvis, P. Crustal thickness constraints on the geodynamic evolution of the Galapagos Volcanic Province. Earth Planet. Sci. Lett. 2003, 214, 545-559. [CrossRef]

36. Gutscher, M.A.; Malavieille, J.; Lallemand, S.; Collot, J.Y. Tectonic segmentation of the North Andean margin: Impact of the Carnegie Ridge collision. Earth Planet. Sci. Lett. 1999, 168, 255-270. [CrossRef]

37. Michaud, F.; Witt, C.; Royer, J.Y. Influence of the subduction of the Carnegie volcanic ridge on Ecuadorian geology: Reality and fiction. In Backbone of the Americas: Shallow Subduction, Plateau Uplift, and Ridge and Terrane Collision; Mahlburg Kay, S., Ramos, V., Dickinson, W., Eds.; The Geological Society of America: Boulder, CO, USA, 2009; pp. 217-228.

38. Blanco-Chao, R.; Pedoja, K.; Witt, C.; Martinod, J.; Husson, L.; Regard, V.; Audin, L.; Nexer, M.; Delcaillau, B.; Saillard, M.; et al. The rock coast of South and Central America. In Memoirs; Geological Society: London, UK, 2014; Volume 40, pp. 155-191. [CrossRef] 
39. Pedoja, K.; Dumont, J.F.; Lamothe, M.; Ortlieb, L.; Collot, J.Y.; Ghaleb, B.; Auclair, M.; Alvarez, V.; Labrousse, B. Plio-Quaternary uplift of the Manta Peninsula and La Plata Island and the subduction of the Carnegie Ridge, central coast of Ecuador. J. South Am. Earth Sci. 2006, 22, 1-21. [CrossRef]

40. White, S.M.; Trenkamp, R.; Kellogg, J.N. Recent crustal deformation and the earthquake cycle along the Ecuador-Colombia subduction zone. Earth Planet. Sci. Lett. 2003, 216, 231-242. [CrossRef]

41. Graindorge, D.; Calahorrano, A.; Charvis, P.; Collot, J.Y.; Bethoux, N. Deep structures of the Ecuador convergent margin and the Carnegie Ridge, possible consequence on great earthquakes recurrence interval. Geophys. Res. Lett. 2004, 31, L04603. [CrossRef]

42. Chlieh, M.; Mothes, P.A.; Nocquet, J.M.; Jarrin, P.; Charvis, P.; Cisneros, D.; Font, Y.; Collot, J.Y.; Villegas-Lanza, J.C.; Rolandone, F.; et al. Distribution of discrete seismic asperities and aseismic slip along the Ecuadorian megathrust. Earth Planet. Sci. Lett. 2014, 400, 292-301. [CrossRef]

43. Nocquet, J.M.; Villegas-Lanza, J.C.; Chlieh, M.; Mothes, P.A.; Rolandone, F.; Jarrin, P.; Cisneros, D.; Alvarado, A.; Audin, L.; Bondoux, F.; et al. Motion of continental slivers and creeping subduction in the northern Andes. Nat. Geosci. 2014, 7, 287-291. [CrossRef]

44. Yepes, H.; Audin, L.; Alvarado, A.; Beauval, C.; Aguilar, J.Y.; Font Cotton, F. A new view for the geodynamics of Ecuador: Implication in seismogenic source definition and seismic hazard assessment. Tectonics 2016, 35, 1249-1279. [CrossRef]

45. Alvarado, A.; Audin, L.; Nocquet, J.M.; Jaillard, E.; Mothes, P.; Jarrín, P.; Segovia, M.; Rolandone, F.; Cisneros, D. Partitioning of oblique convergence in the Northern Andes subduction zone: Migration history and the present-day boundary of the North Andean Sliver in Ecuador. Tectonics 2016, 35, 1048-1065. [CrossRef]

46. Marcaillou, B.; Collot, J.Y.; Ribodetti, A.; d'Acremont, E.; Mahamat, A.A.; Alvarado, A. Seamount subduction at the North-Ecuadorian convergent margin: Effects on structures, inter-seismic coupling and seismogenesis. Earth Planet. Sci. Lett. 2016, 433, 146-158. [CrossRef]

47. Collot, J.Y.; Sanclemente, E.; Nocquet, J.M.; Leprêtre, A.; Ribodetti, A.; Jarrin, P.; Chlieh, M.; Graindorges, D.; Charvis, P. Subducted oceanic relief locks the shallow megathrust in central Ecuador. J. Geophys. Res. B Solid Earth Planets 2017, 122, 3286-3305. [CrossRef]

48. Swenson, J.L.; Beck, S.L. Historical 1942 Ecuador and 1942 Peru subduction earthquakes and earthquake cycles along Colombia-Ecuador and Peru subduction segments. Pure Appl. Geophys. 1996, 146, 67-101. [CrossRef]

49. Ye, L.; Kanamori, H.; Avouac, J.P.; Li, L.; Cheung, K.F.; Lay, T. The 16 April 2016, Mw 7.8 (Ms 7.5) Ecuador earthquake: A quasi-repeat of the 1942 M S 7.5 earthquake and partial re-rupture of the 1906 Ms 8.6 Colombia-Ecuador earthquake. Earth Planet. Sci. Lett. 2016, 454, 248-258. [CrossRef]

50. Gómez-Capera, A.A.; Stucchi, M.; Arcila, M.; Bufaliza, M.; Choy, J.; Minaya, E.; Leyton, L.; Pirchiner, M.; Rendón, H.; Rodriguez, L.; et al. Updated Earthquake Catalogue For South America: Time Window Pre-1964. In Proceedings of the 16th World Conference on Earthquake, 16WCEE 2017, Santiago, Chile, 9-13 January 2017.

51. Beauval, C.; Marinière, J.; Yepes, H.; Audin, L.; Nocquet, J.M.; Alvarado, A.; Baize, S.; Aguilar, J.; Singaucho, J.C.; Jomard, H. A New Seismic Hazard Model for Ecuador. Bull. Seismol. Soc. Am. 2018, 108, 1443-1464. [CrossRef]

52. García-Bustos, S.; Landín, J.; Moreno, R.; Chong, A.S.E.; Mulas, M.; Mite, M.; Cárdenas, N. Statistical analysis of the largest possible earthquake magnitudes on the Ecuadorian coast for selected return periods. Georisk Assess. Manag. Risk Eng. Syst. Geohazards 2018. [CrossRef]

53. He, P.; Hetland, E.A.; Wang, Q.; Ding, K.; Wen, Y.; Zou, R. Coseismic Slip in the 2016 Mw 7.8 Ecuador Earthquake Imaged from Sentinel-1A Radar Interferometry. Seismol. Res. Lett. 2017, 88, 277-286. [CrossRef]

54. Hancox, G.T.; Perrin, N.D.; Dellow, G.D. Recent studies of historical earthquake-induced landsliding, ground damage, and MM intensity in New Zealand. Bull. New Zealand Soc. Earthq. Eng. 2002, 35, 59-95.

55. Reyes, P.; Michaud, F. Mapa Geológico de la Margen Costera Ecuatoriana (1: 500.000); Quito, Ecuador; Institut de recherche pour le développement: Marseille, France, 2012.

56. Kelson, K.; Witter, R.C.; Tassara, A.; Ryder, I.; Ledezma, C.; Montalva, G.; Frost, D.; Sitar, N.R.; Moss Johnson, L. Coseismic tectonic surface deformation during the 2010 Maule, Chile, Mw 8.8 earthquake. Earthq. Spectra 2012, 28, S39-S54. [CrossRef]

57. Wartman, J.; Dunham, L.; Tiwari, B.; Pradel, D. Landslides in Eastern Honshu induced by the 2011 off the Pacific Coast of Tohoku earthquake. Bull. Seismol. Soc. Am. 2013, 103, 1503-1521. [CrossRef] 
58. Serey, A.; Piñero-Feliciangeli, L.; Sepúlveda, S.A.; Iveda, F.; Poblete, D.; Petley, I.; Murphy, W. Landslides induced by the 2010 Chile megathrust earthquake: A comprehensive inventory and correlations with geological and seismic factors. Landslides 2019, 16, 1153. [CrossRef]

59. Sieberg, A. Geologie der Erdbeden. In Handbuch der Geophysik; Harold, J., Ed.; Nature: London, UK, 1930; Volume 2, pp. 550-555.

60. Wood, H.O.; Neumann, F. Modified Mercalli intensity scale of 1931. Bull. Seismol. Soc. Am. 1931, 21, $277-283$.

61. Richter, C.F. Elementary Seismology; Freeman: San Francisco, CA, USA, 1958.

62. Medvedev, S.; Sponheuer, W.; Karník, V. Neue seismische Skala Intensity Scale of Earthquakes, 7. Tagung der Europäischen Seismologischen Kommission vom 24.9. bis 30.9.1962; Institut für Bodendynamik und Erdbebenforschung in Jena: Jena, Germany; Deutsche Akademie der Wissenschaften zu Berlin: Berlin, Germany, 1964.

C 2019 by the authors. Licensee MDPI, Basel, Switzerland. This article is an open access article distributed under the terms and conditions of the Creative Commons Attribution (CC BY) license (http://creativecommons.org/licenses/by/4.0/). 